\title{
Population status and threats to fishing cat Prionailurus viverrinus (Bennett, 1833) in Koshi Tappu Wildlife Reserve, Eastern Nepal
}

\author{
Rama Mishra $^{1,2,3^{*}}$ (D) | Birendra Gautam ${ }^{3}$ (D) Prativa Kaspal ${ }^{4}$ (iD $\mid$ Shyam Kumar Shah ${ }^{5}$ (D)
}

\author{
${ }^{1}$ Department of Biology, Evolutionary Ecology Group, University of Antwerp, Belgium \\ ${ }^{2}$ Wildlife Conservation Association Nepal (WildCAN), Babarmahal, Kathmandu, Nepal \\ ${ }^{3}$ National Trust for Nature Conservation, POB 3712, Khumaltar, Lalitpur, Nepal \\ ${ }^{4}$ Bhaktapur Multiple Campus, Bhaktapur, Nepal \\ ${ }^{5}$ Department of National Parks and Wildlife Conservation, Babarmahal, Kathmandu, Nepal \\ *Correspondence: I.mishrarama@gmail.com
}

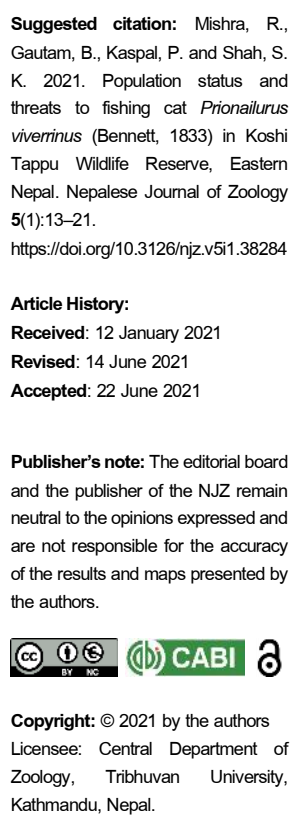

\section{(C) (1) ( (B) $\mathrm{CABI}$ ว}

Copyright: ๑ 2021 by the author Licensee: Central Department of Zoology, Tribhuvan University, Kathmandu, Nepal.

\begin{abstract}
Koshi Tappu Wildlife Reserve (KTWR) in eastern Terai of Nepal is believed to hold a relatively healthy population of vulnerable fishing cats but has remained unexplored. We conducted camera trapping and questionnaire survey in KTWR and its buffer zone in the winter of 2016 and 2017 to estimate the population status and threats to fishing cat Prionailurus viverrinus. Camera trapping was conducted in $\mathbf{2 0 1 6}$ on fish farms in the eastern buffer zone where we found a minimum of nine fishing cat individuals visiting the surveyed fish ponds. The frequency of their visits to fish ponds varied 0-5 (average 2) nights during seven active camera trap nights. A survey in the second year (2017) covered the entire reserve. Spatially Explicit Capture-Recapture models estimated a population of 20 fishing cats with density of $8.4 / 100 \mathrm{~km}^{2}$ in KTWR and the eastern buffer zone. We interviewed 50 fish farmers to understand the people's perceptions towards fishing cats. More than $40 \%$ of the respondents reported fishing cats consuming fish from their farm. Retaliation and road kills were documented as major threats of fishing cats in the study area. The population of the fishing cat is found dependent partially on fish ponds, indicating the possibility of conflict with fish farmers. We recommend the detailed study on the movement of fishing cats between the reserve and fish farming area in the buffer zone.
\end{abstract}

\section{Keywords: Buffer zone; Camera trapping; Pelage pattern; SECR framework; Wetlands}

\section{1 | Introduction}

Fishing cat Prionailurus viverrinus is a globally threatened small cat categorized as Vulnerable 'VU' globally on the IUCN Red List of Threatened Species and Endangered 'EN' nationally in Nepal (Amin et al. 2018; Mukherjee et al. 2016). It is native to south and southeast Asia including Sri Lanka, India, Bangladesh, Pakistan, Thailand, Cambodia, Myanmar, Vietnam, and Nepal with strongholds in the former three countries. The actual global population of fishing cat is not known but it is reported in decreasing trends (Mukherjee et al. 2016). Fishing cat is also called a wetland cat as it depends on wetlands preying primarily on fish. However, they are generalist in feeding habit consuming small mammals, reptiles, crustaceans, birds, invertebrates (Cutter 2015). The patchy distribution close to wetland areas throughout its range indicates its strong association with wetlands.

In most part of its range countries including Nepal, the conversion of large parts of natural wetlands to aquaculture for fish, shrimps and prawn farming has affected fishing cats with loss of their natural preys, increasing human-fishing cat conflicts and retaliatory killing (Chowdhury et al. 2015; Mukherjee et al. 2012; Taylor et al. 2016). Road kills and poaching for fur are additional threats for fishing cats throughout its range (Heinen \& Leisure 1993; Palei et al. 2018). In Nepal, fishing cat is distributed along a narrow stretch in the southern belt of Terai bordering India. It was recorded from Sunsari in the east to Kanchanpur district in the far west with discontinuous distribution between them (Jnawali et al. 2011; Yadav et al. 2020). Five protected areas (PAs) of Terai namely Koshi Tappu Wildlife Reserve (KTWR); Parsa, Chitwan, Bardia and Shuklaphanta National Parks have evidence of fishing cat (Mishra 2016; Poudel et al. 2019; Poudyal et al. 2019; Taylor et al. 2016; Yadav et al. 2020; Yadav et al. 2018). Outside the protected area, it was recorded from three locations in Bankalwa (Sunsari), Bodhban (Bara) and Jagdishpur Reservoir (a Ramsar site in Kapilvastu)(Dahal et al. 2014, 2016; Shrestha 2018). All the locations outside the protected areas comprised of fish farming areas. The fishing cat population in Nepal was estimated between 150 and 200 through expert opinion but population estimates from systematic survey is lacking (Jnawali et al. 2011). A study based on photographic 
capture recapture estimated a population of 18 fishing cats (95\% $\mathrm{Cl}$ of 9-25; density $=6.06$ individuals per $100 \mathrm{~km}^{2}$ ) in Chitwan NP (Mishra 2016). The general faunal surveys rarely report fishing cats from several parts of the Terai (DNPWC \& DOF 2018; Subedi et al. 2020). This is in contrast with the suggestions of Jnawali et al. (2011). However, the species cannot be considered absent from the area. The fishing cat range in Nepal (the Terai region), also have a high-density human population. Fishing cats face various threats in this human-dominated landscape such as habitat loss including wetland destruction and degradation, poisoning and overharvesting of fish, poaching for fur, road kill (Heinen \& Leisure 1993; Jnawali et al. 2011; Mishra 2013).

We conducted this study in the KTWR at eastern lowland Nepal. It is believed that a relatively healthy population of fishing cats exists there (Taylor et al. 2016). We assessed the population status of fishing cat in both core area and buffer zone of the KTWR as well as documented the existing threats to them.

\section{2 | Materials and methods}

\section{1 | Study area}

This study was carried out in Koshi Tappu Wildlife Reserve (KTWR) and its buffer zone (BZ) area (Fig. 1). KTWR lies between $26^{\circ} 34^{\prime}-26^{\circ} 45^{\prime} \mathrm{N}$ and $86^{\circ} 55^{\prime}-87^{\circ} 05^{\prime} \mathrm{E}$ in the Southern part of eastern Nepal. This reserve was established in 1976 with an area of $175 \mathrm{~km}^{2}$ and named after the largest river of Nepal (Koshi, one of the major tributaries of Ganga), primarily for the conservation of last remaining population of wild water buffalo (Bubalus arnee) and a large number of water birds and fishes. The entire KTWR is a part of the floodplain of Koshi River and was listed as the first Ramsar site of Nepal in 1987. Along with Koshi River, the Trijuga River enters the reserve from northwestern part and joins with the Koshi River at the southern part of the reserve. The Koshi River flows north-south separating the habitats into east and west. In the eastern buffer zone, seepage of water from the Koshi River has created a biodiversity rich swampy area supporting a wide range of species including carnivores like fishing cat, jungle cat (Felis chaus), mongooses (Herpestes spp.) and golden jackals (Canis aureus). But these natural water holes are converting into series of private fish ponds and this trend is increasing everyday (Mishra et al. 2020).

In 2004, additional area of $173 \mathrm{~km}^{2}$ surrounding the reserve was declared as BZ. The reserve covers the part of three district Sunsari, Saptari and Udyapur. Its BZ consists of municipalities from all of these districts.

The reserve also hosts several species of globally threatened aquatic fauna like Gangetic dolphin (Platanista gangetica), smooth coated otter (Lutrogale perspicillata), gharial (Gavialis gangeticus), etc. It is a hotspot for the highest number of globally threatened bird species like swamp francolin (Francolinus gularis) and Bengal florican (Houbaropsis bengalensis) and many migratory birds (Chettri et al. 2013).
Grassland covers the large part of habitat in KTWR which is mostly determined by frequently shifting course of the Koshi River. Small patches of forest in between the Koshi's arms occur which is sometimes washed away during flooding. Intense grazing of feral cattle and livestock in the reserve supplements the soil erosion and marshland drying and conversion into other land use, affecting the species relied there. Wetland area in KTWR has decreased over $30 \%$ since its establishment (Chaudhary et al. 2016).

\section{2 | Survey methods}

We conducted two methods for this study of fishing cat in KTWR and its buffer zone.

\section{Questionnaire survey}

In September 2016, semi-structured informal interviews were conducted with fish farmers in the eastern buffer zone of KTWR before starting the camera traps. Out of $\sim 200$ fish farms in the study area, we selected 50 fish farms randomly with spatial coverage of the survey area and interviewed with the farm owner or care takers. The purpose of this interview was to understand the farmers' attitudes towards fishing cats, its threats and to obtain information for camera trapping survey. We also asked for their consent to install camera traps in their fish farms if the farm is selected for camera trapping based on the study design.

\section{Camera trapping}

Camera trapping was carried out in November and December of two consecutive years of 2016 and 2017. Digital motion sensor

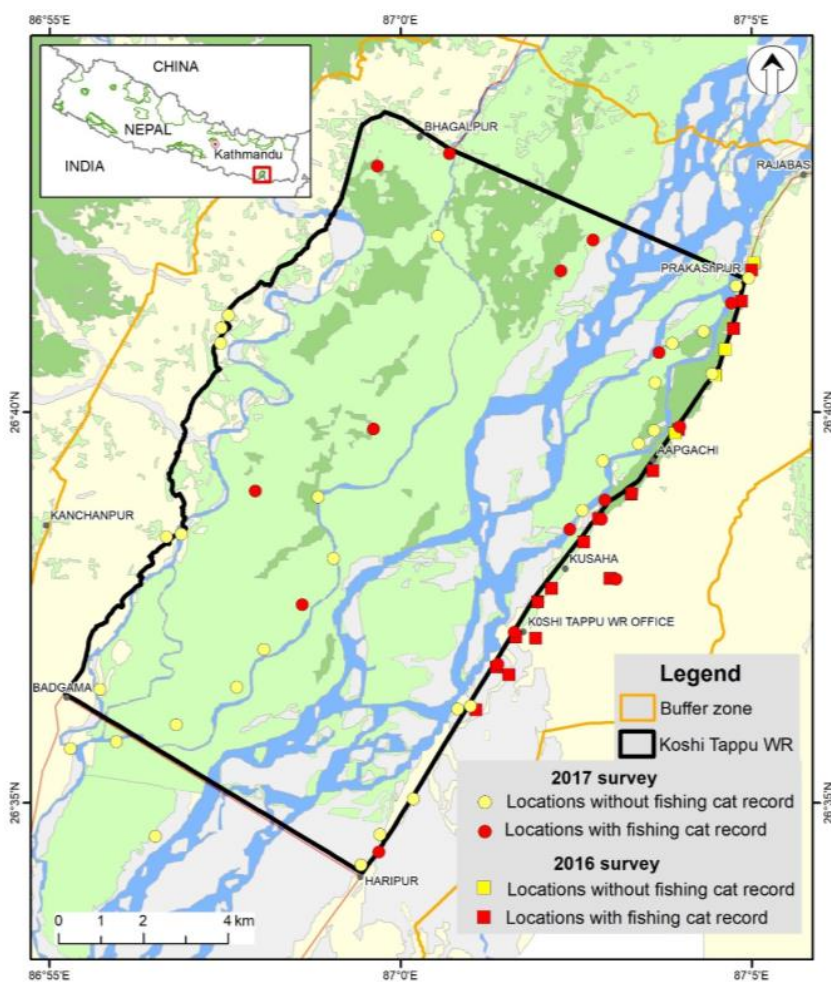

Figure 1. Study area (Koshi Tappu Wildlife Reserve and buffer zone) showing locations of camera traps and fishing cat record during the fishing cat survey in 2016 and 2017. 
cameras of Reconyx Hyperfire HC550, Bushnell Trophy Cam HD and Cuddeback model were set up in the field for continuous seven days and nights (Mishra et al. 2020). Cameras were set to take three pictures per trigger followed by 10 second video. Camera-traps were mounted on bamboo poles $30-45 \mathrm{~cm}$ above the ground, and 2-3 $\mathrm{m}$ apart on either side of game trails, marshes and riverbeds without using lure. Garmin eTrex was used to record the GPS coordinates of camera trap locations and other signs of fishing cats.

In the first year (2016), the camera trapping was conducted only at the fish farms to quantify the farm use by fishing cats. For this, from the sample $(n=50)$ of fish farms a subsample $(n=20)$ were selected for camera trapping, spread evenly across the area to ensure the spatial coverage of the study area. From each sample farm, a suitable fish pond for deploying camera traps was selected. Accessibility to the pond and probable trails of animals or human trails were prioritized for installing camera traps. Two to four cameras were placed singly in each pond to ensure the maximum capture of fishing cats visiting the farm.

In the second year (2017), camera traps were deployed both at the fish farms and core area of the reserve to estimate the population size of fishing cats at KTWR through photographic capture recapture. To ensure images of both sides of each fishing cat individuals, we placed paired cameras (Cutter 2009). The cameras were deployed in two successive shifts due to limited numbers of cameras available. First shift covered the eastern side with 27 camera stations including both fish farms $(n=11)$ and core areas of the reserve $(n=16)$. Subsequently after the first shift, all cameras were moved to western part for the second shift. There were no private fish ponds in the western BZ of KTWR and all cameras were deployed $(n=22)$ in the major tributary of Koshi River, bank of Trijuga River and nature swamps and marshy areas inside the reserve with suitable habitat of fishing cats.

\section{3 | Data analysis}

\section{Data from camera trapping}

All data obtained from camera traps for both the years were entered systematically into Microsoft Office Excel 2010 along with the time and dates of images taken. The images of different species obtained were filtered and independent events of fishing cats were calculated for further analysis. The images of fishing cats were considered as independent events if photographs were taken in the time interval of one hour (Mishra et al. 2018; Negrões et al. 2010). We used spatially explicit capture-recapture analysis using program SPACECAP to estimate the population and density of fishing cats in KTWR (Gopalaswamy et al. 2012; Lamichhane et al. 2019). This program is a user-friendly software package for estimating animal densities using closed model capture-recapture sampling based on photographic captures. With the assumption that each individual of fishing cats have distinct and complex pelage patterns of black dots and streaks on its body, the images obtained from camera traps were carefully examined for their individual identification (Fig. 2) (Cutter 2009; Mishra et al. 2018).
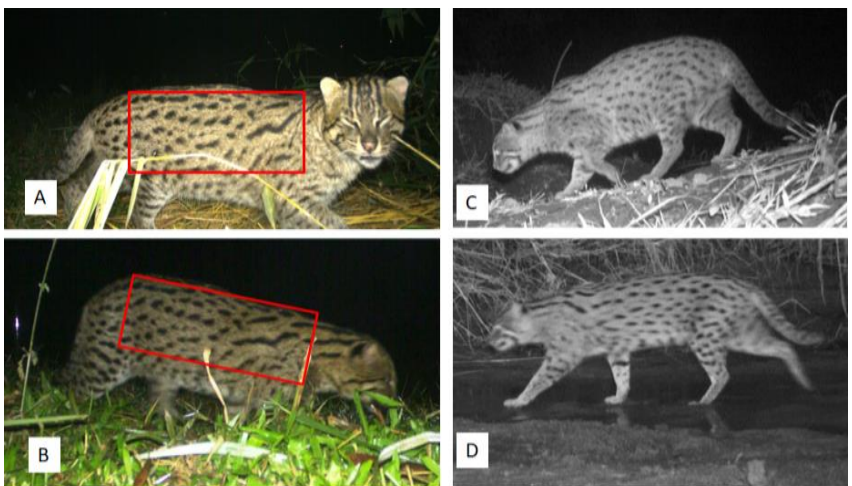

Figure 2. Individual identification using pelage pattern of the fishing cats. The photos 'A' \& 'B' belong to same individual and 'C' \& 'D' belong to different individuals.

\section{Estimating population and density}

We estimated density and population size of fishing cats through Bayesian Spatially-Explicit Capture-Recapture (B-SECR) models implemented in the package 'SPACECAP' (Gopalaswamy et al. 2012) in $R$ 3.4.0 ( $R$ Core Team, 2020). SPACECAP requires three input files i.e. (1) capture history with location, animal ID and sampling occasion; (2) camera activity records (1--active and 0 -not-active) for each camera-trap location and sampling occasion; and ( 3 ) home range centers represented by continuous points at $100 \mathrm{~m}$ spacing (0-non habitat, 1-habitat) around $5 \mathrm{~km}$ buffer of the camera locations. This resulted in an area of $231 \mathrm{~km}^{2}$ of fishing cat habitat after removing the $259 \mathrm{~km}^{2}$ area of settlements, agriculture and built up area. We ran the analysis with four different combinations (1) trap response present, (2) trap response absent, (3) half-normal and (4) negativeexponential detection functions and reported the density and population size obtained from the best-performing model (Gopalaswamy et al. 2012). We ran a Markov Chain Monte Carlo (MCMC) over 51,000 iterations with a burn-in of 1,000 and a thinning rate of 5 . An augmentation value of 85 (more than five times the number of animals captured or $M t+1$ ) was set. We produced a pixelated map of fishing cat density at the size of home range center (1 ha) using QGIS v.2.7 (QGIS Development Team 2016).

\section{3 | Results}

\section{1 | Respondent characteristics}

We interviewed 50 respondents of age 20 to 65 years with an average of 47 years. Seven of the respondents were females. Most of the respondents were owners of the fish ponds while, two had fish pond on lease and two were employee working on the fish ponds. The size of the fish ponds varied from one Kattha $\left(338 \mathrm{~m}^{2}\right)$ to 56 Kattha and the numbers of fish ponds per farmer ranges from single to ten with an average of 2.27. Majority of the fish farmers had integrated agriculture and livestock rearing. Very few of them depend on fish farm only. 
Table 1. Income generating source of respondents in the survey area

\begin{tabular}{|l|l|}
\hline Income source of respondents for their livelihood & $\begin{array}{l}\text { No. of } \\
\text { respondents }\end{array}$ \\
\hline Solely depending on fish farm & 3 \\
\hline Fish farm and agriculture & 10 \\
\hline Fish farm, agriculture and livestock/poultry & 27 \\
\hline $\begin{array}{l}\text { Fish farm, agriculture and livestock/poultry \& other } \\
\text { employment (owning shops, hotel business, } \\
\text { employee in other institutions, etc.) }\end{array}$ & 10 \\
\hline Total & \\
\hline & $\mathbf{5 0}$ \\
\hline
\end{tabular}

They reported eight different types of wildlife visiting their fish ponds including four mammal species (fishing cat, otters, jungle cat and jackal), three types of reptiles (mugger crocodiles, monitor lizards and snakes) and several types of birds. They reported birds as the most frequently visiting wildlife in their fish ponds followed by marsh mugger crocodile, otter, fishing cat and jungle cat. Ten of the respondents had reported the sighting of fishing cat around their fish farm whilst one saw fishing cat preying fish in his pond. Twenty-two (>40\%) farmers think fishing cats cause loss in income from their fish farm.

Table 2. Measures to protect fishing cat on respondent's perspective

\begin{tabular}{|l|l|}
\hline Measures & No. of Respondents \\
\hline Compensation to farmers for fish loss & 7 \\
\hline Ditches/Dikes and Fencing/Concrete wall & 18 \\
\hline Natural source maintenance inside reserve & 4 \\
\hline Raise awareness programs in community & 15 \\
\hline No views/Neutral & 6 \\
\hline
\end{tabular}

\section{2 | Threats to fishing cats}

Within the previous five years of the survey (2012-2016), minimum of six fishing cats were killed by retaliation and road kill. Eight of the respondents reported retaliation of fishing cats in their area using snare, guard dog and electrocution (putting live electric wire around their fish farm). Two of the respondents reported road kill of fishing cat in Haripur (South-East of the reserve) while crossing the highway (Fig. 3). To reduce the conflict with communities and possible retaliation, respondents suggested making barriers at fish ponds to restrict fishing cat's movement, raising awareness in the community and providing compensation for the loss of fish from fishing cats.

\section{3 | Fish ponds use by fishing cats}

In 2016, the camera trapping effort of 140 trap days from 20 fish farms resulted a total of 309 photos and nine videos of fishing cats in 56 independent detections with capture rate of 40 detections per 100 trap days. Fishing cats were photographed from 16 out of 20 fish farms where cameras were installed (Supplementary Table 1). Among the 16 ponds with records of fishing cats, nine belong to ponds where conflict with fishing cats is reported during interview and seven belong to the ponds

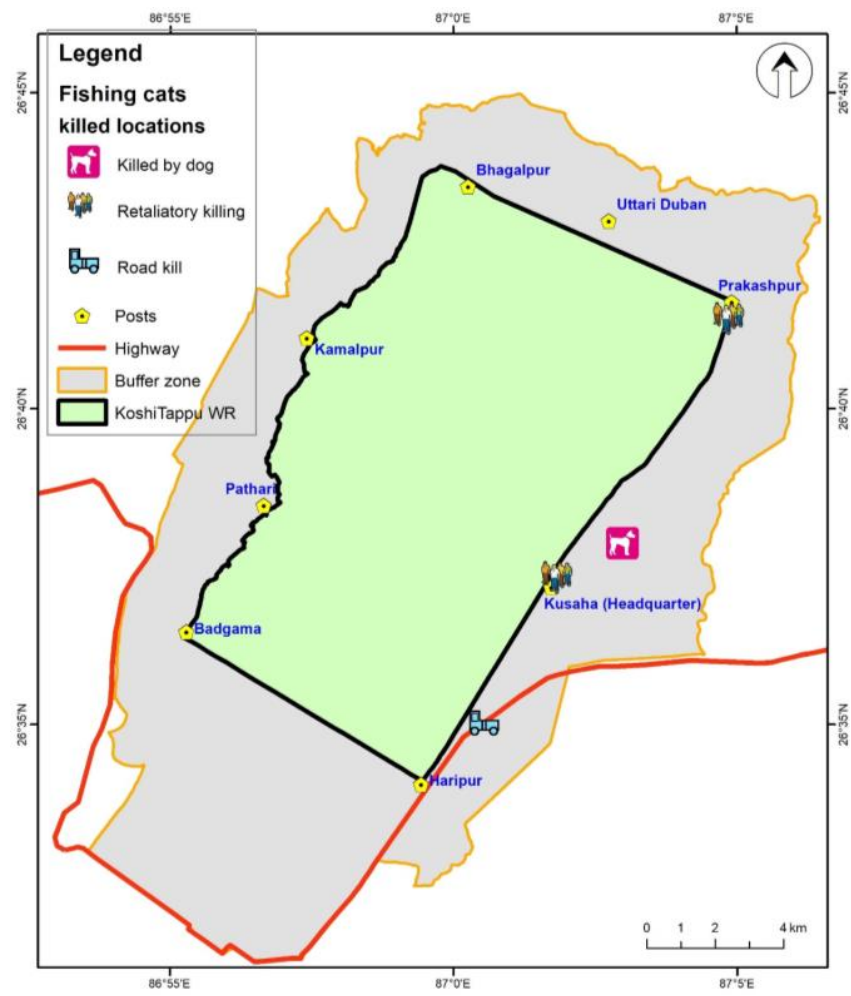

Figure 3. Locations of fishing cat death records due to various reasons in Koshi Tappu Wildlife Reserve and buffer zone in eastern Nepal.

where no conflict was reported. As single camera was placed in each location, photos of either left or right flank was obtained. From the pelage patterns nine separate right flanks and nine separate left flanks were identified. All the images of fishing cats were obtained during night. We identified at least nine fishing cats in the Eastern BZ area. Of these, five were identified as females and four as males (Table 3). In addition, sex of one individual with only right flank pictures could not be determined. If this individual is different than the previously identified, the fishing cat individuals' number recorded during survey will be 10 .

Besides fishing cats, camera traps also obtained images of jungle cat, porcupine, mongooses, small Indian civet, golden jackal, wild elephant, wild water buffalo, domestic cat and dog, cattle and human.
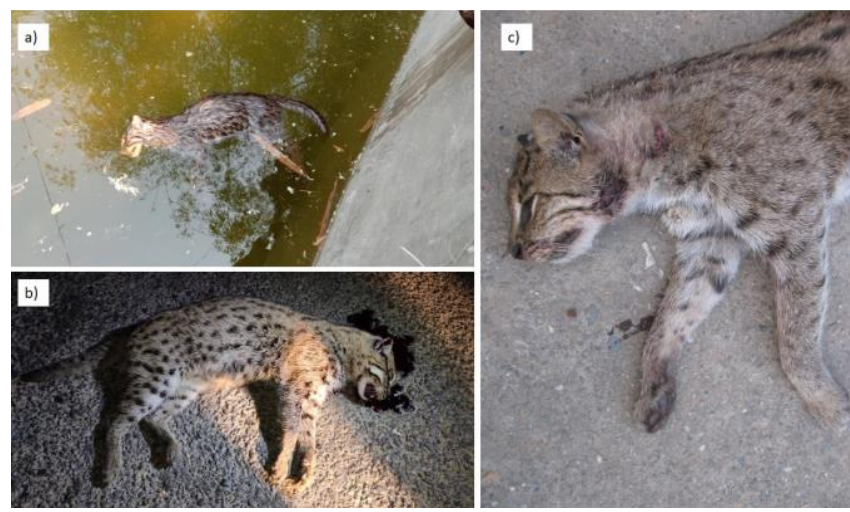

Figure 4. Dead fishing cats; a) drowned in a concrete fish pond in BZ of KTWR (Photo credit: P. Adhikari), b) road kill in Bara district of Central Terai (Photo credit: S. Khadka), and c) Fishing cat suspected to be attacked by leopard in Chitwan National Park (Photo credit: B. R. Lamichhane). 
Table 3. Flanks and sex of fishing cat photographed during camera trapping survey in the eastern BZ of KTWR during Nov-Dec 2016.

\begin{tabular}{|l|l|l|l|l|}
\hline Fishing cats & Females & Males & Sex unknown & Total \\
\hline Both Right \& Left flanks & 3 & 1 & & 4 \\
\hline Right flank only & 2 & 2 & 1 & 5 \\
\hline Left flank only & 2 & 3 & & 5 \\
\hline Total Right flank & 5 & 3 & 1 & 9 \\
\hline Total Left flank & 5 & 4 & & 9 \\
\hline
\end{tabular}

\section{4 | Population density and abundance}

In 2017, the camera trapping effort of 385 days from 49 locations in KTWR and buffer zone resulted 446 photos and 102 videos of fishing cats in 75 independent detections with the capture rate of 19.48 detections per 100 trap days. Among these, four of the detections from the core part of reserve were obtained during daylights hours. Seventeen fishing cat individuals were identified from the camera trap images including six males, six females and sex of five individuals is undetermined through the images. Eight fishing cats ( 3 males, 3 females and 2 unidentified sex) are recorded from the eastern part of KTWR and nine ( 3 male, 3 females and 3 are unrecognized sex) from western side. Whilst comparing the camera trapping images obtained from both years, four of fishing cats are found captured in both years in the eastern $B Z$ of KTWR.

The population estimation of fishing cat in Koshi Tappu Wildlife Reserve using SECR framework shows $20 \pm 3$ SD (95\% Cl $14-$ $25)$ and density $8.4 \pm 1.3 \mathrm{SD}(95 \% \mathrm{Cl} 6.05-10.81)$ individuals per $100 \mathrm{~km}^{2}$

\section{4 | Discussion}

We conducted the first comprehensive analysis of fishing cat population density in the Koshi Tappu Wildlife Reserve (KTWR) and documented relatively small population of fishing cats. The population density of fishing cat in KTWR found higher (8.4 individuals per $100 \mathrm{~km}^{2}$ ) than that of Chitwan National Park (CNP; 6.06 individuals per $100 \mathrm{~km}^{2}$ ) (Mishra 2016). The population density in CNP was calculated covering only the wetland areas of $160 \mathrm{~km}^{2}$ whereas the entire area of KTWR was covered. It indicates that in general, the habitat of KTWR is better than that of CNP for fishing cats. The fishing cats visited $80 \%$ of the private fish ponds in the buffer zone of Koshi indicating their high dependency on the ponds. We found that fish farms are expanding in the area, providing extended habitat for the fishing cats, but it also increases the threats of retaliatory killing.

Most of fishing cat detections ( $n=127$ ) obtained from the camera traps combined for both years (trapping effort of 525 trap days; total images/videos - 866) were during the night. All the fishing cat record around fish ponds were during the dark hours (17:10$06: 15)$ but they were also photographed in daylight hours $(06: 15$ 17:10) ( $n=4$ detections) in the undisturbed habitat (core area of the reserve). Fishing cats may be adopting with the surrounding environment through temporal shift in their activities to co-exist with the humans.

Based on camera trapping survey, the detection rate of fishing cat in fish ponds area is twice (40 detections/100 trap days) than in the reserve (19.48 per 100 trap days). It suggests that fishing cats visits the fish farms more frequently than the natural wetlands in the reserve. Also, it is not clear whether fishing cats are visiting ponds to preying on fish or other animals. Despite frequent visits of fishing cats on the fish farms, we did not find any conclusive evident (photographs or feeding signs) of fishing cats consuming fish. Though there is chance of fishing cats to kill small fish and consume the whole body without leaving the sign; remains (bones, scales or other parts) of big fish should remain and detected (Adámek et al. 2003). We also documented single fishing cat visiting several fish ponds in same night indicating that fishing cat's use of ponds is not limited to preying fish. Rather fishing cats may have moved around ponds in search of other diet such as snakes, frogs, rats and other invertebrates around the agricultural land adjoining the ponds.

Recapture rate of fishing cat is high in the eastern side of reserve than in the western part. This may be probably due to presence of numbers of private fish pond in the eastern BZ which may have contributed diet to fishing cats. Also abandoned marsh land with native fishes, frogs and invertebrates; crops field of farmers with snakes and rats may lure the fishing cats to visit there more often (Mishra et al. 2020). Likewise, huge water mass of Koshi River may restrict the movement of fishing cats from Eastern to Western sites. In a point we can say that the habitat in eastern boundary of KTWR is suitable to hold a good number of fishing cats in small area. However, in a marshy location with shallow water but rich of native fishes in the western part of the reserve, fishing cat was photographed almost every night. Every night it appears and seen spending half to one-hour time in that area. In one of the events, a fishing cat was seen holding fish in its mouth. Whilst at the same time fishing cats photographed in cameras around the tributaries of Koshi and Trijuga River were not recaptured. Due to wide range of river, the fishing cat may have moved to lager areas reducing the chances of recapture at a point location. Or, it might be the fishing cats spending most of their time in marshy land and less frequently visits the river side.

In contrast to the respondent's assumptions of large number of fishing cats (over 100) we obtained photographs of less than 20 individuals through an intensive camera trap survey in the reserve and buffer zone. Retaliatory killing of even a single fishing cat will thus have an immense impact to the fishing cat population in Koshi region. Some farmers have understood the conservation value of fishing cats and wanted to protect them. Farmers are happy to protect fishing cats if there is provision for the prevention of fishing cat's movement in their fish farm by any means of barriers like fence, ditches etc. But this might have impact on the breeding population of fishing cat which still need to be studied. Also, farmers believe, the fishing cat will be 
protected if they are provided with the relief for the loss of their fish.

We also documented the breeding of fishing cat in Koshi. In a location at the bank of Koshi River arms in the eastern side close to the fish farming area, we recorded a fishing cat with her three kitten multiple times in a camera trap within a week of installing camera. We left the cameras at the location for additional two weeks. However, the fishing cat and kitten did not return to the location for the next two weeks. The cat may have moved to another location.

Fish farmers have reported several species of wildlife visiting the fish farms and consume fish in the eastern BZ. Some of them have also reported direct sighting of crocodiles and python entering in their ponds and preying fish. Sometimes these reptiles remain inside the ponds for a long time until removed from the pond. Wetland birds also prey on fishes of different size relative to their body mass. Except one, none of the respondents have reported the sighting of fishing cat preying fish in their pond. Fishing cats are active in the dark hours, and fish farmers primarily visit their farms in the daytime, which may have reduced the chances of fishing cat sighting there. Despite some reports of loss from fishing cats and other wildlife, the number of fish farms are increasing in the eastern buffer zone area, indicating that the loss from fishing cats and other wildlife is not detrimental and fish farm is still beneficial business in the area.

Questionnaire survey shows the diverse income source of the fish farmers for their livelihoods. Only few of them were dependent exclusively on fish farming. Majority of farmers practice an integrated farming with aquaculture, animal husbandry and agriculture. Some of them also have other income source like hotel or salaried job. Most of them are interested to promote tourism with fishing cats. An excellent example of tourism linked with fishing cats are available in West Bengal, India where locals have established home stays (Baghrol Basa, or fishing cat lodging) offering fishing cat photographic tours to the visitors (Kolipaka et al. 2019). Similar branding and marketing of homestays with fishing cat as one of the key attractions can be promoted around Koshi Tappu area.

Retaliatory killing of fishing cat was the major cause of mortality in the BZ of KTWR. Most of the respondents hesitate to explain the retaliation events in fear of detention by authorities. However, one of the respondents told that he had killed over twenty fishing cats in the last couple of decades due to his ignorance but stopped retaliation at present. According to the other respondent his guard dog had killed fishing cat in his fish farm five months before this survey period. Movement of the dogs around the fish farms recorded in the camera traps supports the statement of the respondent. Similar findings about fishing cat threats is explained in other range countries like India, Bangladesh and Thailand (Adhya et al. 2011; Chowdhury et al. 2015; Cutter 2015). Apart from dogs, movement of domestic cats and livestock around the fish farms as well as core areas of the reserve poses the threats of infectious disease transmission to fishing cats (Suzán \& Ceballos 2005; Taetzsch et al. 2018).

A villager also reported to one of the authors (Birendra Gautam) about fishing cat death after entangling in fence around the fish ponds in 2018 which confirms the prevalence of unintentional killing. Recently (April 2021), a fishing cat was found drowned in a concrete fish pond within the eastern BZ of Koshi (personal communication with Ashok Ram, Chief Conservation Officer KTWR). We assumed that the cat jumped into the pond to prey fish and could not come out of it due to high vertical wall of the pond (Fig. 4a).

Moreover, fishing cats are also killed in road accidents. Road crossing by cats is regarded as bad omen by many drivers and they try to kill the cat crossing the road, including the fishing cats. We found two incidents of the roadkill in Koshi. One of the retired government officers also recalls road kill during 1990s in Koshi (personal communications with Bed Bahadur Khadka). The first author also recorded the road kill of fishing cat in Bara district in central Terai (Fig. 4b). Sometimes fishing cats are also killed by stronger predators such as tigers and leopards. Attack of a leopard was suspected as a cause of death of a female fishing cat found dead in eastern sector of CNP in 2010 with deep injury on its neck (personal communication with Babu Ram Lamichhane, Fig. 4c).

Moreover, the local people also reported fishing cats predating chickens but without conclusive evidence. Jungle cats also visit the fish ponds frequently (Mishra et al. 2020), and it is possible that local people misidentified the cats entered their villages. A satellite collared study of fishing cats will help to answer this and understand the fishing cat movement at the fish farm or village areas. It also helps to quantify the extent of conflict/interaction of fishing cats with locals in buffer zone. In addition to this, the collars will provide important information on ecology (home range, nesting sites, habit, habitat, and feeding behavior) of fishing cats which contribute in future conservation programs.

Previous studies suggest that fishing cats prefer ponds, lakes and marshes (Mishra et al. 2018) than to flowing rivers and streams. However, a record of the species in the Babai River by Yadav et al. (2018); and of this study records in the bank of Trijuga and the Koshi River indicates the species can occur equally in flowing water system too.

In contrast to the claims of over $60 \%$ of the respondents about otters visiting their fish ponds and consuming fish, we didn't record any otter in both years of camera trapping. We also failed to detect any sign of otters during our survey areas. Also, we found some respondent misidentified fishing cats with the otters. Some respondent also claims that they have seen fishing cats in group of five to twenty, which is impossible as fishing cats are solitary. It demonstrates that the questionnaire survey can be biased and may not depict the reality (Allendorf et al. 2020). 


\section{5 | Conclusions}

Although KTWR and its buffer zone consists a good habitat for fishing cats, the population of fishing cat is comparatively low. Fishing cats are evenly distributed in the fish farming areas in the eastern BZ and in the core reserve area in the western side in both lotic or lentic ecosystems, with high frequency of visits to fish ponds. These cats are under the threat of different anthropogenic pressures like retaliation, road kills, habitat encroachment and conversion of wetlands into fish ponds. For the conservation of the species a detailed behavior and ecological study of fishing cat is needed.

\section{6 | Research implications}

The study demonstrated the small population of fishing cat population in the study area and the loss caused by them to fish farmers is minimal. This information is helpful to convince the locals to save fishing cats. We suggest conducting a detailed study on spatial movement, habitat use and ranging behaviors of fishing cat in human dominated landscape.

\section{Acknowledgements}

We thank National Trust for Nature Conservation (NTNC), Nepal and Koshi Tappu Wildlife Reserve for their support in this study. We like to acknowledge Taronga Foundation for providing the grants for fishing cat research. We thank Department of National Parks and Wildlife Conservation for permitting to conduct this survey. We acknowledge the contribution of Dr. Iain R. Taylor for initiating and fundraising for the project and Dr. Naresh Subedi for assisting to implement the project smoothly. We would like to thank Dr. Babu Ram Lamichhane for his assistance to analyze the data. We would like to thank the technicians of NTNC Mr. Purna Lama, Mr. Deep Prasad Chaudhary and Mr. Ramesh Darai who helped in the field for camera trap survey. We also like to thank staffs of KTWR especially Mr. Binda Sardar, Mr. Dev Kumar Biswas, Mr. Arjun Karki and Ms. Bunu Rana. Finally, we like to thank the local communities including Mr. Bimal Mandal and Mr. Gulabi Mukhiya who allowed camera trap in their fish farm area and supported directly/indirectly during fieldwork.

\section{Authors' contributions}

Mishra, R., Gautam, B. and Kaspal, P. designed the survey; all authors conducted the field survey; Mishra, R. analyzed the data and prepared the first draft; and all authors reviewed and gave final approval for publication.

\section{Conflicts of interest}

Authors declare no conflict of interest.

\section{ORCID}

Rama Mishra (iD https://orcid.org/0000-0002-8648-7256
Birendra Gautam iD https://orcid.org/0000-0001-7406-3416

Prativa Kaspal iD https://orcid.org/0000-0003-0591-9086

Shyam Kumar Shah (iD https://orcid.org/0000-0002-0893-6968

\section{References}

Adámek, Z., Kortan, D., Lepic, P. and Andreji, J. 2003. Impacts of otter (Lutra lutra L.) predation on fishponds: A study of fish remains at ponds in the Czech Republic. Aquaculture International 11:389-396. https://doi.org/10.1023/A:1025787330366

Adhya, T., Dey, P., Das, U. and Hazra, P. 2011. Status survey of Fishing Cat (Prionailurus viverrinus) in Howrah and Hooghley, West Bengal. Report Submitted to the Small Grants Programme, WWF India, New Delhi.

Allendorf, T. D., Gurung, B., Poudel, S., Dahal, S. and Thapa, S. 2020. Using community knowledge to identify potential hotspots of mammal diversity in southeastern Nepal. Biodiversity and Conservation 29:933-946. https://doi.org/10.1007/s10531-01901919-0

Amin, R., Baral, H. S., Lamichhane, B. R., Poudyal, L. P., Lee, S., Jnawali, S. R., Acharya, K. P., Upadhyaya, G. P., Pandey, M. B., Shrestha, R., Joshi, D., Griffiths, J., Khatiwada, A. P. and Subedi, N. 2018. The status of Nepal's mammals. Journal of Threatened Taxa 10:11361-11378.

https://doi.org/10.11609/jott.3712.10.3.11361-11378

Chaudhary, S., Chettri, N., Uddin, K., Khatri, T. B., Dhakal, M., Bajracharya, B. and Ning, W. 2016. Implications of land cover change on ecosystems services and people's dependency: A case study from the Koshi Tappu Wildlife Reserve, Nepal. Ecological Complexity 28:200-211.

https://doi.org/10.1016/j.ecocom.2016.04.002

Chettri, N., Uddin, K., Chaudhary, S. and Sharma, E. 2013. Linking Spatio-temporal land cover change to biodiversity conservation in the Koshi Tappu Wildlife Reserve, Nepal. Diversity 5:335351. https://doi.org/10.3390/d5020335

Chowdhury, S. U., Chowdhury, A. R., Ahmed, S. and Muzaffar, S. B. 2015. Human-fishing cat conflicts and conservation needs of fishing cats in Bangladesh. Cat News 62:4-7.

Cutter, P. 2009. Camera trapping and conservation status assessment of fishing cats at Khao Sam Roi Yod National Park, Thailand and surrounding areas. Occasional Report. Fishing Cat Research and Conservation Project, Thailand.

Cutter, P. 2015. Fishing cat ecology: food habits, home ranges, habitat use and mortality in a human-dominated landscape around Khao Sam Roi Yot, Peninsular Thailand. MSc Thesis, University of Minnesota, USA.

Dahal, S., Appel, A., Shrestha, S., Dahal, D. R. and Gurung, S. 2016. Re-assessing and identifying the conservation needs of fishing cat in Bankalwa, Sunsari, Nepal. Report submitted to Rufford Foundation, UK.

Dahal, S., Baral, S., Nepal, M., Neupane, K. R., Dahal, B. V. and Basnet, K. 2014. Status of fishing cat in Jagdishpur Reservoir and Ghodaghodi lake and assessment of threat. Report submitted to MBZ Species Conservation Fund. Small Mammals Conservation and Research Foundation, Kathmandu, Nepal. 
DNPWC and DFSC. 2018. Status of tigers and prey in Nepal. Department of National Parks and Wildlife Conservation \& Department of Forests and Soil Conservation. Ministry of Forests and Environment, Kathmandu, Nepal.

Gopalaswamy, A. M., Royle, J. A., Hines, J. E., Singh, P., Jathanna, D., Kumar, N. S. and Karanth, K. U. 2012. Program SPACECAP: Software for estimating animal density using spatially explicit capture-recapture models. Methods in Ecology and Evolution 3:1067-1072. https://doi.org/10.1111/j.2041-210X.2012.00241.x

Heinen, J. T. and Leisure, B. 1993. A new look at the Himalayan fur trade. Oryx 27:231-238.

Jnawali, S. R., Baral, H. S., Lee, S., Acharya, K. P., Upadhyaya, G. P., Pandey, M., Shrestha, R., Joshi, D., Lamichhane, B. R., Griffiths, J., Khatiwada, A. P., Subedi, N. and Amin, R. 2011. The status of Nepal's mammals: The National Red List Series. Department of National Parks and Wildlife Conservation, Kathmandu, Nepal.

Kolipaka, S. S., Srivastava, D. P., Prasad, S. and Rust, N. A. 2019. Fishing cat conservation in human-dominated landscapes in West Bengal, India. Cat News 69:21-24.

Lamichhane, B. R., Leirs, H., Persoon, G. A., Subedi, N., Dhakal, M., Oli, B. N., Reynaert, S., Sluydts, V., Pokheral, C. P. and Poudyal, L. P. 2019. Factors associated with co-occurrence of large carnivores in a human-dominated landscape. Biodiversity and Conservation 28:1473-1491.

https://doi.org/10.1007/s10531-019-01737-4

Mishra, R. 2013. Conservation status of fishing cat in Chitwan National Park, Nepal. MSc Thesis, Tribhuvan University, Kirtipur, Kathmandu, Nepal.

Mishra, R. 2016. Conservation status of the Fishing Cat in Chitwan National Park, Nepal. In A. Appel \& J. W. Duckworth (Eds.), First International Fishing Cat Conservation Symposium, November, 2015 (pp. 25-26). Fishing Cat Working Group.

Mishra, R., Basnet, K., Amin, R., \& Lamichhane, B. R. 2018. Fishing cat Prionailurus viverrinus (Bennett, 1833) (Carnivora: Felidae) distribution and habitat characteristics in Chitwan National Park, Nepal. Journal of Threatened Taxa 10:12451-12458. https://doi.org/10.11609/jot.3426.10.11.12451-12458

Mishra, R., Gautam, B., Shah, S. K., Subedi, N., Pokheral, C. P. and Lamichhane, B. R. 2020. Opportunistic records of jungle cat (Felis chaus) and their activity pattern in Koshi Tappu Wildlife Reserve, Nepal. Nepalese Journal of Zoology 4:50-55. https://doi.org/10.3126/njz.v4i1.30673

Mukherjee, S., Adhya, T., Thatte, P. and Ramakrishnan, U. 2012. Survey of the fishing cat Prionailurus viverrinus (Bennett, 1833) (Carnivora: Felidae) and some aspects impacting its conservation in India. Journal of Threatened Taxa 4:3355-3361. https://doi.org/10.11609/JoTT.03199.3355-61

Mukherjee, S., Appel, A., Duckworth, J. W., Sanderson, J., Dahal, S., Willcox, D. H. A., Herranz Muñoz, V., Malla, G., Ratnayaka, A., Kantimahanti, M., Thudugala, A., Thaung, R. and Rahman, H. 2016. Fishing Cat Prionailurus viverrinus.

https://doi.org/http://dx.doi.org/10.2305/IUCN.UK.20162.RLTS.T18150A50662615.en

Subedi, N., Bhattarai, S., Pandey, M., Gurung, A., Lamichhane, S., Thapa, S.K, Regmi, R, Parsai, A, Regmi P, and Lamichhane B.R. 2020. Summary report on faunal diversity in chure region of Nepal. President Chure-Terai Madhesh Conservation
Development Board and National Trust for Nature Conservation, Kathmandu, Nepal.

Negrões, N., Sarmento, P., Cruz, J., Eira, C., Revilla, E., Fonseca, C., Sollmann, R., Torres, N. M., Furtado, M. M. and Jácomo, A. T. A. 2010. Use of camera-trapping to estimate puma density and influencing factors in central Brazil. The Journal of Wildlife Management 74:1195-1203. https://doi.org/10.2193/2009-256

Poudel, S., Lamichhane, B. R., Bhattarai, S., Adhikari, D., Pokheral, C. P., Bhatta, T. R., Giri, S. R., Lamichhane, S., Sadaula, A., Gurung, A., Poudyal, L. P., Regmi, U. R. and Subedi, N. 2019. First photographic evidence of fishing cat Prionailurus viverrinus (Bennett, 1833) and clouded leopard Neofelis nebulosa Griffith, 1821 (Carnivora: Felidae) in Parsa National Park, Nepal. Journal of Threatened Taxa 11:13497-13501. https://doi.org/10.11609/jott.4549.11.4.13497-13501

Poudyal, L. P., Lamichhane, B. R., Paudel, U., Niroula, S. R., Prasai, A., Malla, S., Subedi, N., Thapa, K. and Dahal, B. R. 2019. Mammals of Shuklaphanta: An Account from Camera Trap Survey (First edition). Shuklaphanta National Park Office, Kanchanpur, Nepal.

QGIS Development Team. 2016. QGIS Version 2.7. Retrieved from: http://www.qgis.org/en/site/

R Core Team. 2020. R: A language and environment for statistical computing. R Foundation. https://www.r-project.org/

Shekhar Palei, H., Pratap Das, U. and Debata, S. 2018. The vulnerable fishing cat Prionailurus viverrinus in Odisha, eastern India: status and conservation implications. Zoology and Ecology 28:69-74. https://doi.org/10.1080/21658005.2018.1468646

Shrestha, S. 2018. Assessment of human-fishing cat conflict in the human-dominated landscape of central tarai, Nepal. MSc thesis, Tribhuvan University, Kathmandu, Nepal.

Suzán, G. and Ceballos, G. 2005. The role of feral mammals on wildlife infectious disease prevalence in two nature reserves within Mexico City limits. Journal of Zoo and Wildlife Medicine 36:479484. https://doi.org/10.1638/04-078.1

Taetzsch, S. J., Bertke, A. S. and Gruszynski, K. R. 2018. Zoonotic disease transmission associated with feral cats in a metropolitan area: A geospatial analysis. Zoonoses and Public Health 65:412-419. https://doi.org/10.1111/zph.12449

Taylor, I. R., Baral, H. S., Pandey, P. and Kaspal, P. 2016. The conservation status of the fishing cat Prionailurus viverrinus (Bennett, 1833) (Carnivora: Felidae) In Koshi Tappu Wildlife Reserve, Nepal. Journal of Threatened Taxa 8:8323-8332. https://doi.org/10.11609/jott.2034.8.1.8323-8332

Yadav, B. P., Appel, A., Shrestha, B. P., Dahal, B. R. and Dhakal, M. 2020. The fishing cat Prionailurus viverrinus (Bennett, 1833) (Mammalia: Carnivora: Felidae) in Shuklaphanta National Park, Nepal. Journal of Threatened Taxa 12:17203-17212. https://doi.org/10.11609/jott.6145.12.16.17203-17212

Yadav, S. K., Lamichhane, B. R., Subedi, N. and Dhakal, M. 2018. Fishing cat camera trapped in Babai Valley of Bardia National Park, Nepal. Cat News 67:31-33. 
Supplementary Table 1. Fish pond use pattern by fishing cats during surveyed period (Nov - Dec 2016) at fish farms in the eastern BZ of $K T W R(F=F e m a l e, M=M a l e, U=S e x$ unidentified individuals, $D=$ Unclear photo/videos of fishing cats - individuals cannot be identified and discarded, Number after M and F (e.g. M1) represents the Fishing Cat ID).

\begin{tabular}{|c|c|c|c|c|c|c|c|c|c|c|c|c|c|c|c|c|}
\hline \multirow{2}{*}{ Pond (CT) } & \multicolumn{15}{|c|}{ Camera trapping date (November/December, 2016) } & \multirow{2}{*}{ No. of nights FC visited } \\
\hline & Nov 17 & 18 & 19 & 20 & 21 & 22 & 23 & 24 & 25 & 26 & 27 & 28 & 29 & 30 & Dec 1 & \\
\hline P01 & & & & & & & & & & & & & & & & 0 \\
\hline P02 & M1 & & & & & & & & & & & & & & & 1 \\
\hline P03 & M2 & & & & & & & & & & & & & & & 1 \\
\hline P04 & M3 & & & & & & & & & & & & & & & 1 \\
\hline P05 & & F4 & & M1 & F4 & M2 & & F4 & & & \multicolumn{4}{|c|}{ camera not active } & & 5 \\
\hline P06 & & & F4 & M1 & & & M1 & & & & & & & & & 3 \\
\hline P07 & & M1 & & & & & $\mathrm{D}^{*}$ & & & & & & & & & 2 \\
\hline P08 & & M1 & & & U5 & F6 & $\mathrm{D}^{*}$ & & & & & & & & & 4 \\
\hline P09 & & $D^{*}$ & & & & & & $D^{*}$ & & & & & & & & 2 \\
\hline P10 & & M1 & F7, F8M9, D* & & & F7 & F10, F11 & & & & & & & & & 4 \\
\hline P11 & & & & & & & & & & & M2 & & & & & 1 \\
\hline P12 & & & & & & & & & & & & & & & & 0 \\
\hline P13 & & & & & & & & & & & & & & & & 0 \\
\hline P14 & & & & & & & & & & & & & & & & 0 \\
\hline P15 & & & Camera not ac & & & & & & & & & & F7, F11 & & & 1 \\
\hline P16 & & & & & & & & & M1 & M1 & & & F8 & & F6 & 4 \\
\hline P17 & & & & & & & & & & & F12 & & M3 & F12 & F12 & 4 \\
\hline P18 & & & & & & & & & & $D^{*}$ & & F8 & & & & 2 \\
\hline P19 & & & & & & & & & & F7, M9, F11, M13 & $F 7, D^{*}$ & & & & $D^{*}$ & 3 \\
\hline P20 & & & & & & & & & & & $D^{*}$ & & & & & 1 \\
\hline
\end{tabular}

